(C) 2002 The Chemical Society of Japan

- - 般 論 文—

\title{
ヘキサフルオロプロピレンオキシドと環状エーテルとの 反応による環状エーテルの重合体の合成
}

\author{
（2001年 10 月 15 日受理）
}

増㴊泰之·萩原時男 ${ }^{* \dagger} \cdot$ ·池谷洋一†·河田盛寿

\begin{abstract}
フッ素含有率の高いヘキサフルオロプロピレンオキシド (HFPO) と環状エーテルとの反応による重合 について検討を行った。モノマーとして六員環エーテルであるテトラヒドロピラン (THP)を用いたと きには，重合体は得られなかった．四員環エーテルであるオキセタン，拈よ゙゙三員環エーテルであるプ ロピレンオキシド (PO)をモノマーとして用いたときに重合生成物が得られた.

モノマーとしてオキセタンを用いたときに，最も高分子量の重合体を得ることができ，その数平均分 子量は $4.8 \times 10^{3}$ であった。これは，オキセタンの開環重合反応性が，環状エーテルの中で最も高いた めであると考えられる。

モノマーとしてプロピレンオキシド (PO)を用いたときに得られる重合生成物は, 他の環状エーテル をモノマーとしたときに得られる重合生成物とは異なる構造であった。これは，PO が他の環状モノ マーに比べてかさ高いこと，および $\mathrm{PO}$ の環の開裂の方向が $\alpha, \beta$ の双方で起るためであると考えられ る.
\end{abstract}

\section{1 緒訔}

フッ素含有率の高いエポキシドであるへキサフルオロプロピレ ンオキシド(HFPO)についての研究は 1960 年代から行われてい $ろ^{11}$.

HFPO は，ラジカル重合せず，アニオン重合ではフッ化物イ オンを生じやすいため連鎖移動を起こしやすく2), カチオン重合 では，異性化してへキサフルオロアセトンを生じるため重合しな (3)などの理由から, 単独での重合反応性にそしいモノマーで, 高分子体を得ることがきわめて難しい. 実際これまでのところ, $\mathrm{CsF}$ を開始剤としたアニオン重合によるオリゴマーの合成が報 告されているのみである4). しかし，HFPO 重合体はオリゴマー であっても熱安定性や化学的安定性が高いことから, 耐熱性, 耐 溶剂性潤滑油として利用されてきている。ささらに，HFPO はぺ ルフルオロビニルエーテルなどの合成に用いられるなど，含フッ 素材料の開発に大きくかかわっている5).

HFPO に関する研究の中で, 興味深い反応としてHFPO と THF の反応が挙げられる. THF は HFPO の反応溶媒として使 用されることの多い物質であるが，触媒不在下で HFPO と反応 し，低分子量ながらも重合体を生成する ${ }^{6)}$.しかし，この反応は 開始剤を用いる重合反応においては，開始剤との開始反応に比べ きわめて遅いので, THF を重合溶媒として使用しても重合反応

東京農工大学工学部, 184-8588 小金井市中町 2-24-16

†埼玉工業大学工学部, 369-0293 埼玉県大里郡岡部町普 済寺 1690
全体に影響を及ぼすことはなく，無視できる。また無触媒下で HFPO と THF の反応で生成される重合体中の HFPO の含有率 は低く，この HFPO と THF の反応はこれまでほとんど注目さ れなかった．しかし，含フッ素ポリエーテルの重合例はこれまで 報告が限られており，この反応に着目，応用することにより新規 重合体合成法が開発できればその意義は大きい.

本研究では, 環状エーテルとして, テトラヒドロピラン (THP), オキセタン, プロピレンオキシド (PO)を用いて, HFPO との無触媒での反応を行った．これらの環状エーテルと HFPO との反応については，これまで詳細な検討が成されてい ない。三員環，四員環，六員環エーテルをモノマーとする重合反 応では，これまでの五員環の THF を用いたときとは分子量，お よび構造の異なる重合体が得られると期待される.

\section{2 実験}

\section{1 試料}

ヘキサフルオロプロピレンオキシド (HFPO : 日本メクトロン 製) は市販品をそのまま用いた。プロピレンオキシド $(\mathrm{PO})$, オキ セタン, テトラヒドロピラン $(\mathrm{THP})$ はすべて窒素雾囲気下, 水 素化カルシウムにより脱水, 蒸留にて精製した.

\section{2 重合方法}

重合はすべて窒素雾囲気下，ガラスアンプル管中に環状エーテ ルモノマー, HFPO を諸定量加えた後, 熔封して行った. 所定 時間反応後，アンプル管を開封し，多量の純水中に投入し，沈殿 した重合体を単離した，得られた重合体はクロロホルムにて希釈 
し, 硫酸ナトリウムにて乾燥させ, 蒸発器にて濃縮した後, 6 時 間減圧乾燥を行った.

\section{3 測定}

NMR 測定は溶媒にクロロホルム- $d$ を用いて行った。（測定装 置：日本電子秼製 JNM-ECP 500)。 GPC の測定は THF を溶 離液として行い, 平均分子量はポリスチレン換算の分子量として 求めた (カラム: TSKgel $\mathrm{GMH}_{\mathrm{XL}} \mathrm{X} 2$-Shodex $\mathrm{KF}-802$ カラムシ リーズ, 検出器 : 日立 $\mathrm{L}-7490$ 形 RI 検出器). GPC のピークが 正の部分から分子量を求めた. 共重合体の HFPO と環状エーテ ルの組成比は, ${ }^{1} \mathrm{H}-\mathrm{NMR}$ 抢よび定量的測定での ${ }^{13} \mathrm{C}-\mathrm{NMR}$ スペ クトルの, ピーク強度比から求めた.

\section{3 結果および考察}

\subsection{HFPO と環状エーテルの反応による重合}

HFPO と環状エーテルの反応による重合の結果を，比較実験 として行った THF を用いた場合の結果とともに Table 1 に示す.

THP をモノマーとして使用した場合に拈いては，初期に重合 体らしきものが得られるが，そのまま放置すると分解して褐色の 液状物質のみが得られた。この液状物質の収率は $13-22 \%$ であ ったが，その分子量はモノマーの分子量とほとんど差がなく， THP と HFPO の反応では, 重合における開始反応に相当する反 応は起るものの, 重合反応は進行しないと考えられる.THPに おいて，重合体が得られなかったのは，THPがまったく開環重 合反応性を持たないからであると考えられる.

オキセタンをモノマーとして使用した場合では，重合体と考え られる生成物が得られた。単離された生成物はいずれも無色のグ リース状で, 収率は 49-93\%, 数平均分子量は $2.7-4.8 \times 10^{3}$ であったＰとＨFPO の反応に抢いても，重合体が得られ， それらの外観は無色のグリース状で，収率は $28-48 \%$, 数平均 分子量は $0.8-1.7 \times 10^{3}$ であった。 いずれの場合においても， THF を用いたときよりも，得られた重合生成物の分子量は高 く, 特にオキセタンを使用した場合では高分子量の重合体が得ら れた。

Table 1 Polymerization reaction of cyclic ethers (CE) with $\mathrm{HFPO}^{\mathrm{a})}$

\begin{tabular}{rlccc}
\hline Rum & CE & CE $/$ HFRO & Yield\% ${ }^{\text {b) }}$ & $\bar{M}_{\mathrm{n}} \times 10^{-3}$ \\
\hline 1 & THP & $51 / 49$ & 20 & 0.2 \\
2 & & $84 / 16$ & 22 & 0.1 \\
3 & & $91 / 9$ & 13 & 0.2 \\
4 & Oxetane & $62 / 38$ & 49 & 2.7 \\
5 & & $89 / 11$ & 93 & 4.0 \\
6 & & $94 / 6$ & 91 & 4.8 \\
7 & PO & $60 / 40$ & 48 & 0.8 \\
8 & & $88 / 12$ & 32 & 0.9 \\
9 & & $94 / 6$ & 28 & 1.7 \\
10 & \multirow{2}{*}{ THF } & $57 / 43$ & 42 & 0.6 \\
11 & & $86 / 14$ & 42 & 1.1 \\
12 & & $93 / 7$ & 37 & 1.1 \\
\hline
\end{tabular}

a) Polymn. temp.: $20^{\circ} \mathrm{C}$., Polymn. time: $24 \mathrm{~h}$.

b) Yied $(\%)=\{($ polymer obtained, $g) /($ total amount monomer fed, g) $\} \times 100$.

\subsection{HFPO と環状エーテルの反応による重合反応生成物の構} 造

Fig. 1 にHFPO とオキセタンの Fig. 2 に HFPO と PO との反 応によって得られた重合生成物の GPC を示す。モノマーとして オキセタン, POいずれを用いても, 低分子領域に屈折率が溶離 液の THF より低い重合体が含まれていることが観測される，才 キセタンをモノマーとしたとき，才キセタンの仕込み比を増やす と屈折率の低い重合体は観測されなくなるが，PO を使用した場

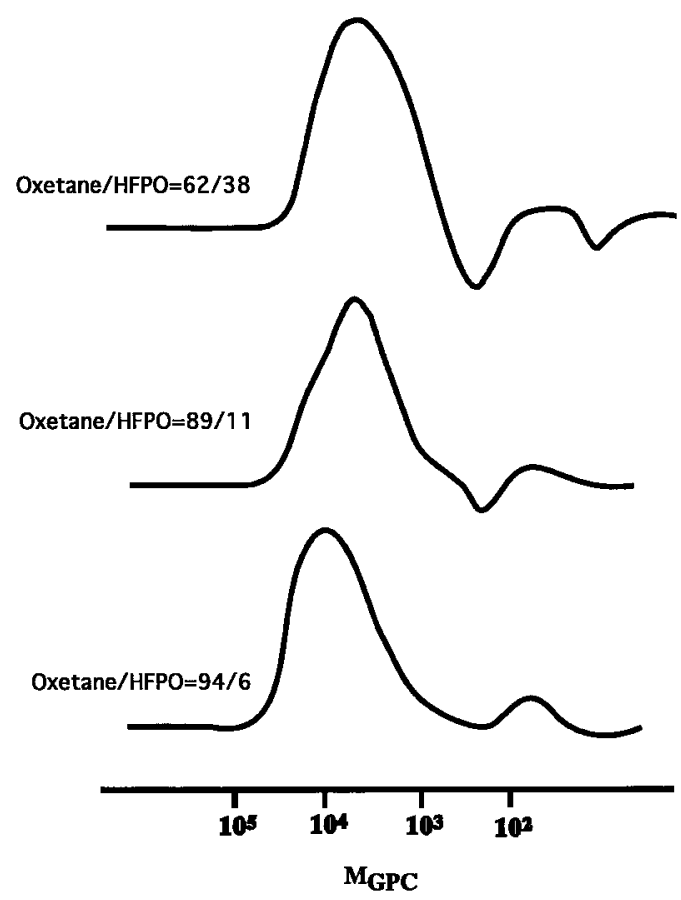

Fig. 1 GPC curves of polymers using Oxetane as a monomer.

$\mathrm{PO} / \mathrm{HFPO}=60 / 40$

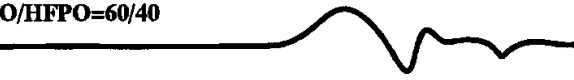

\section{PO/HFPO $=88 / 12$}

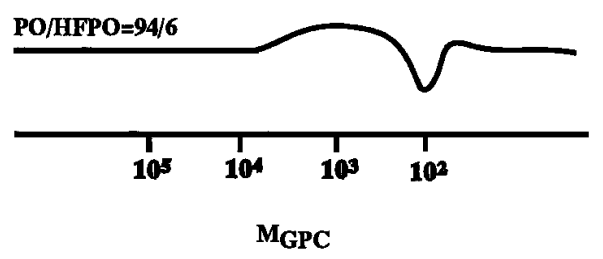

Fig. 2 GPC curves of polymers using PO as a monomer. 
合には，その仕込み比によらず常に観測されている.

HFPO とオキセタンおよびPO との反応で得られた重合生成

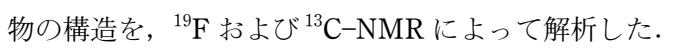

オキセタンを使用したときの重合反応生成物 (Run4)の NMR スペクトルを Fig. 3 に示す. ${ }^{19} \mathrm{~F}-\mathrm{NMR}(\mathrm{A})$ に抢いて $-80 \mathrm{ppm}$ 付 近にトリフルオロメチル基 $\left(\mathrm{CF}_{3}\right),-130 \mathrm{ppm}$ 付近にフルオロメ チン基 $(\mathrm{CF})$ ，そして $-218 \mathrm{ppm}$ 付近にモノフルオロメチル基 $\left(\mathrm{CH}_{2} \mathrm{~F}\right)$ に由来するピークがそれぞれ観測された。しかしなが

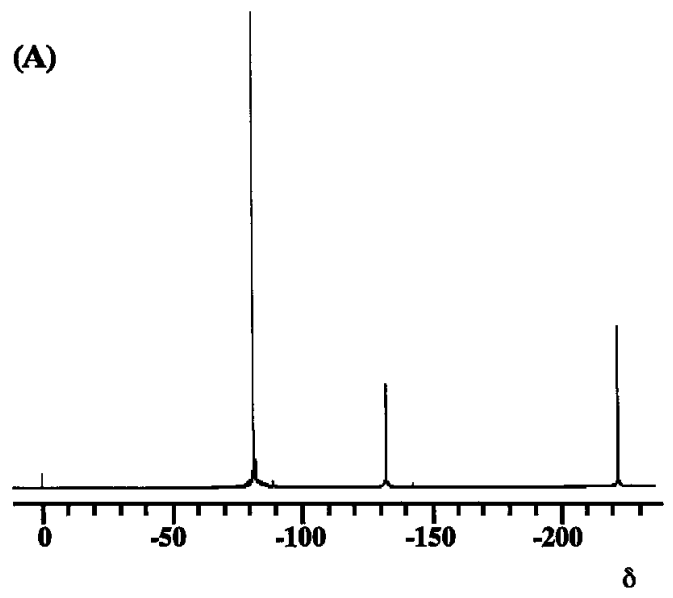

(B)

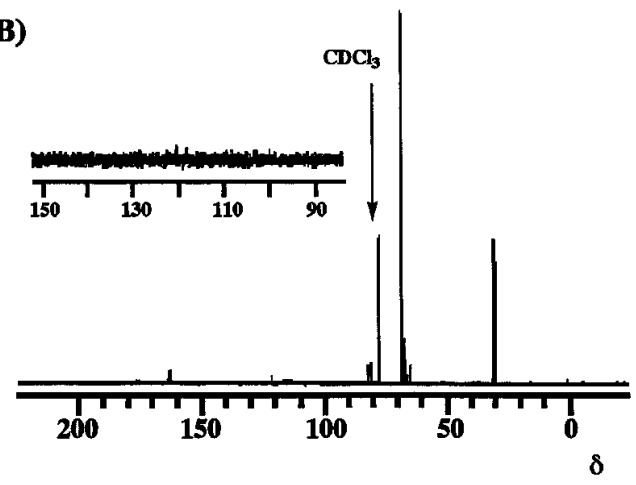

Fig. $3{ }^{19} \mathrm{~F}$ NMR (A) and ${ }^{13} \mathrm{C}-\mathrm{NMR}(\mathrm{B})$ spectra of polymer using oxetane as a monomer.
ら，ジフルオロメチレン基 $\left(\mathrm{CF}_{2}\right)$ に由来するピークは観測できな かった. 一方, ${ }^{13} \mathrm{C}-\mathrm{NMR}$ スペクトルからは, オキセタン単位の ピークと $\mathrm{CH}_{2} \mathrm{~F}$ に由来するピークは観測できたが，水素を持た ないフルオロカーボンに由来するピークはノイズに隠れて観測す ることができなかった。これは重合体中の HFPO 単位の含有率

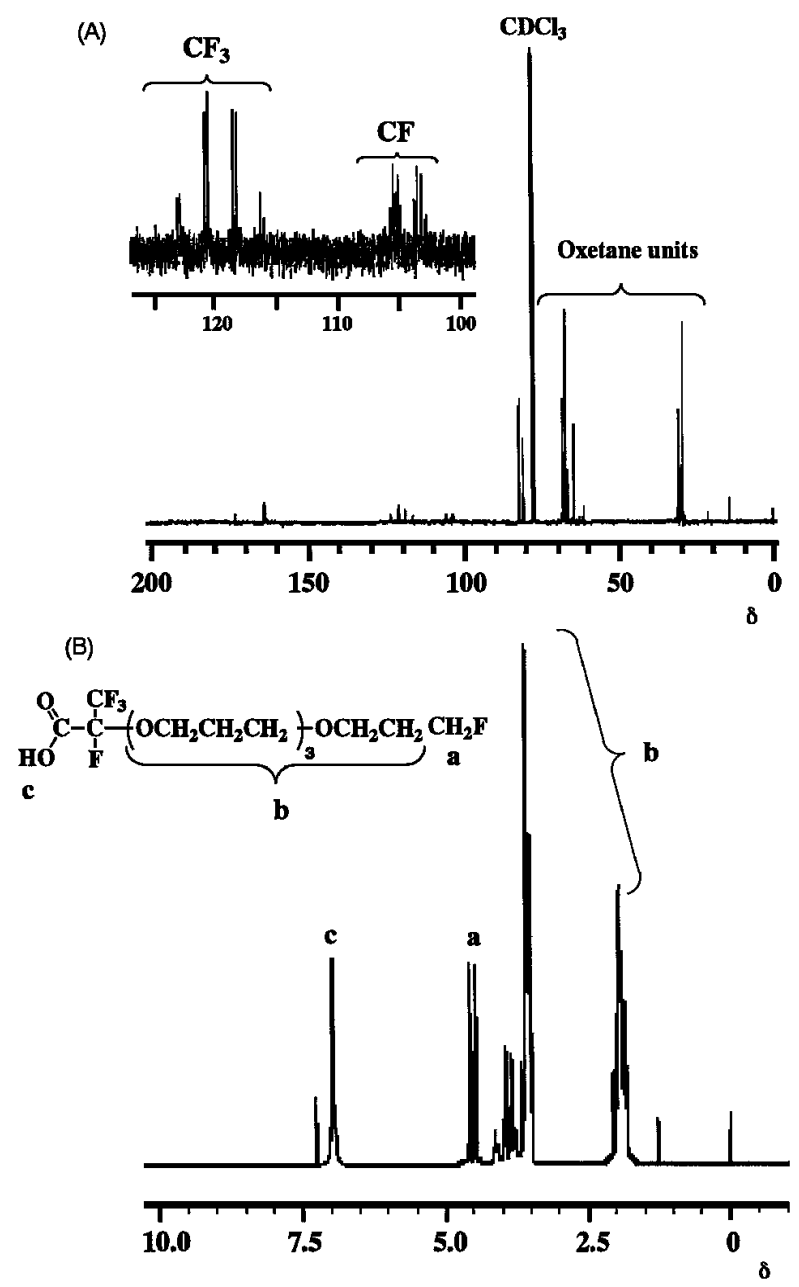

Fig. $4{ }^{13} \mathrm{C}-\mathrm{NMR}(\mathrm{A})$ and ${ }^{1} \mathrm{H}-\mathrm{NMR}(\mathrm{B})$ spectra of polymer (low moleculare weight region) using oxetane as a monomer.

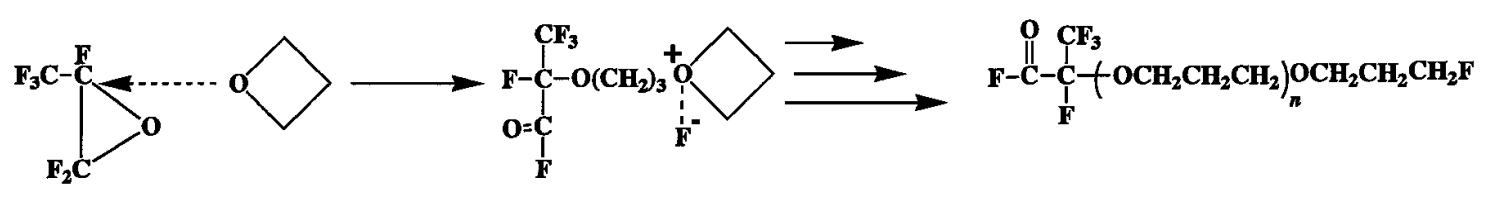<smiles>CCOCCCOC(C)(F)C(=O)OCCOCC</smiles>

Low refractive index region: $n=2$ 
が低いためであると考えられる，そこで，GPCクロマトグラム で低屈折率を示した低分子領域を単離し解析を行った，一般に, フッ素含有率の多い含フッ素ポリマーは低い屈折率を示すことか ら, この領域の重合体中の HFPO 含有率は高いと考えられる.

単離精製は, カラムクロマトグラフィー(溶離溶媒 : ヘキサン/ 酢酸エチル $=1 / 3(\mathrm{v} / \mathrm{v}))$ にて Run 4 の生成物を使用して行った. 単離した低分子領域の構造解析は NMR を用いて行った. 結果を Fig. 4 に示す. ${ }^{13} \mathrm{C}-\mathrm{NMR}(\mathrm{A})$ においてはこれまで観測できなか った，水素を有しないフルオロカーボン $\left(\mathrm{CF}_{3}, \mathrm{CF}\right)$ のピークがは っきり観測されているが， $\mathrm{CF}_{2}$ に䚻属されるピークは観測されな かった。 ${ }^{19} \mathrm{~F}-\mathrm{NMR}$ の結果と照らし合わせて考えると，この重合 生成物中には $\mathrm{CF}_{2}$ は存在しないと考えられる。 また, NMRの ピーク強度の比較から $\mathrm{CF}_{3}, \mathrm{CF}, \mathrm{CH}_{2} \mathrm{~F}$ の比率はすべて等しいこ

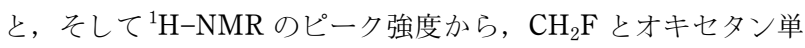
位の比は 1 対 8 であることがわかった。これらの結果から, HFPO によるオキセタンの重合生成物は THF のケースと同様の 機構で進行し, Scheme 1 に示す構造を与えると考えられる. 同 様の反応機構でありながら，モノマーを THF としたときと才キ セタンとしたときとで重合生成物の分子量に大きく差が生じるの は，それぞれのエーテルの重合反応性の違いが原因であると考え られる.この反応の開始段階は HFPO への環状エーテルの求核 反応であるが，生長段階はオキソニウムイオン生長となるため, 環状エーテルの開環重合反応性が重合反応全体に大きく影響す る。つまり, THFに比べて重合反応性が高いオキセタンでは, 生長反応が速くなり高分子量体が生成したと考えられる.

一方，PO をモノマーとした重合生成物では ${ }^{19} \mathrm{~F}-\mathrm{NMR}$ スペク トル上に，オキセタンとの反応では観測されなかった $\mathrm{CF}_{2}$ に由 来するピークが観測されている(Fig. 5)． $\mathrm{CF}_{2}$ の消失は, 開始段 階において, HFPO の $\alpha$ 炭素が求核的に攻撃されることが原因 と考えられる. HFPO と PO の反応による重合において $\mathrm{CF}_{2}$ が 消失しないのは, PO はオキセタンや THF に比べ, かさ高い構
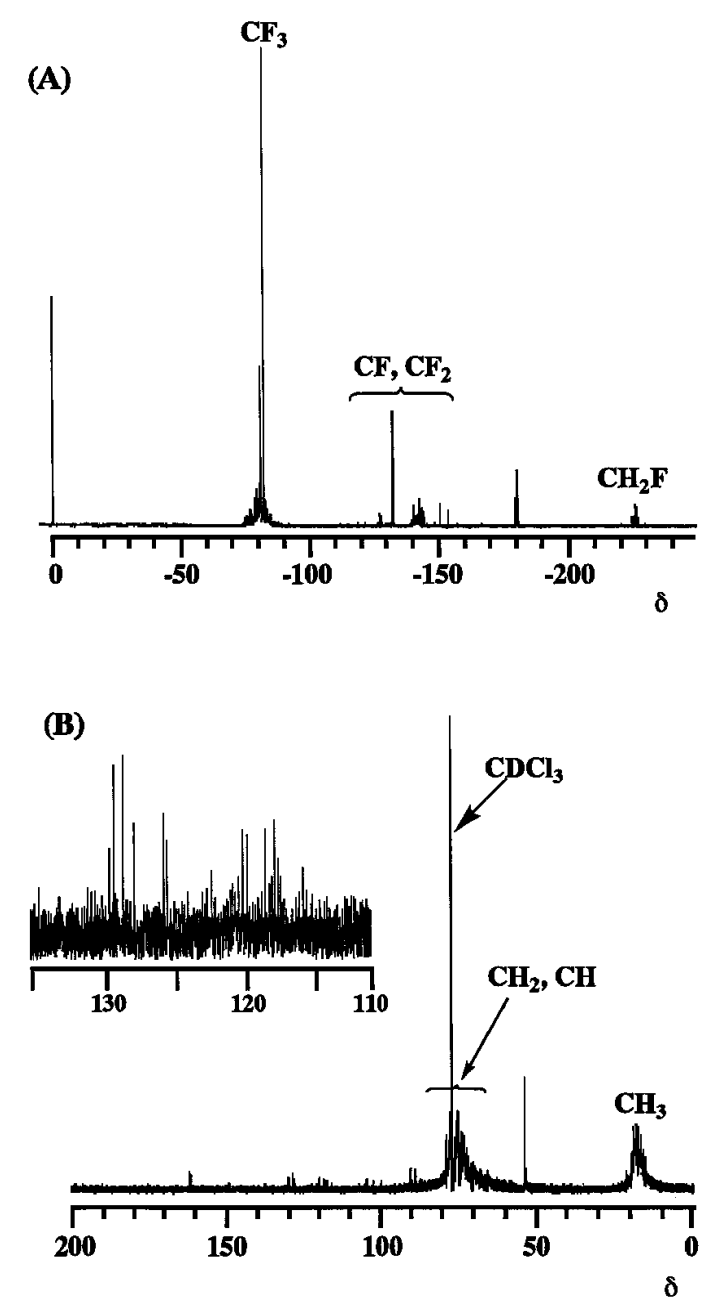

Fig. $5{ }^{19} \mathrm{~F}-\mathrm{NMR}(\mathrm{A})$ and ${ }^{13} \mathrm{C}-\mathrm{NMR}(\mathrm{B})$ spectra of obtained polymer using $\mathrm{PO}$ as a monomer.

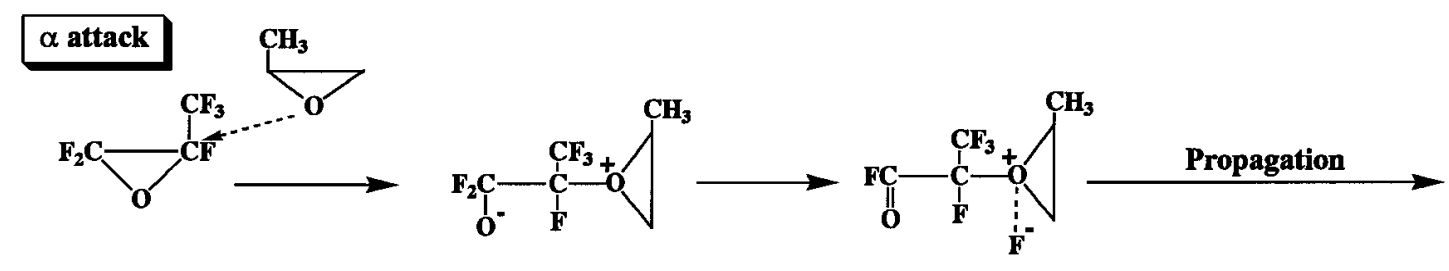

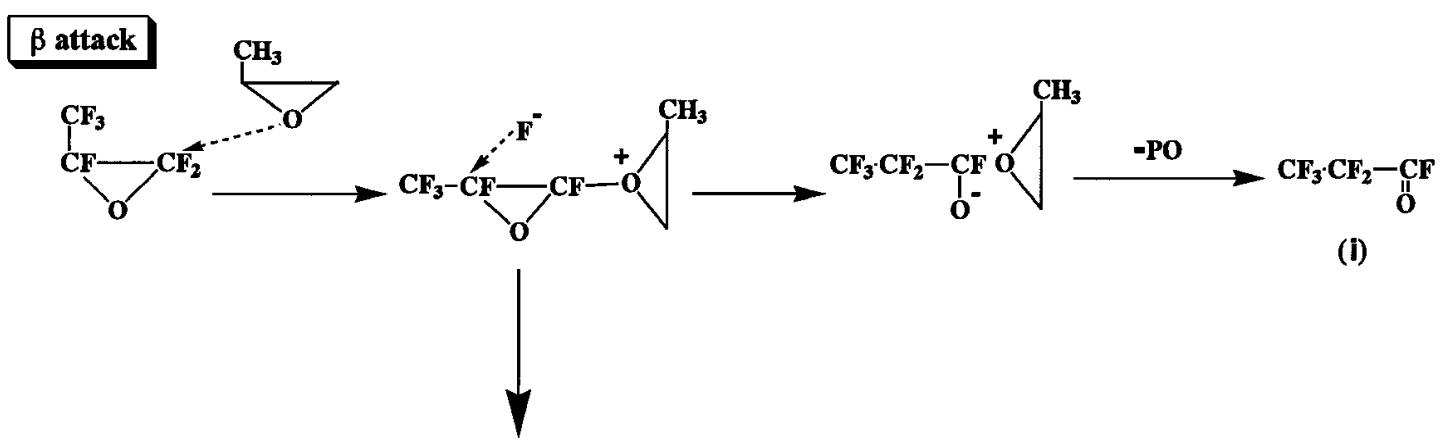

\section{Cyclic oligomer}

(II) 
造であるため, HFPO の $\beta$ 炭素への攻撃が起こっている可能性 が考えられる. 実際, HFPO と求核試薬の反応において, トリ エチルアミンのようなかさ高い塩基の求核反応に拈いては HFPO の $\beta$ 炭素への攻撃が起きることが報告されている7)。 また， ${ }^{19} \mathrm{~F}-\mathrm{NMR}$ スペクトル上には $\mathrm{CH}_{2} \mathrm{~F}$ も観測されている．このこと は, HFPO の $\alpha$ 炭素へのPO の攻撃も同時に起きていることを 示唆している. つまり, HFPOへのPOの求核攻撃は $\alpha, \beta$ の両 方の炭素に対して起こると考えられる. Scheme 2 に示すよう に，重合反応は HFPO の $\alpha$ 炭素に PO の攻撃が起きたときにの み進行する、このとき, 重合はカチオン機構で進行するが, PO はカチオン機構において $\alpha$ 開裂， $\beta$ 開裂のどちらでも開裂の可能 性があり ${ }^{8)}$, これにより生成される重合体の主鎖のモノマー単位 の配向, 配列は不規則なものになると考えられる. ${ }^{13} \mathrm{C}-\mathrm{NMR}$ ス ペクトルの, 複雑な形状はこの重合体主鎖のモノマー単位の不規 則な配向, 配列を反映している. 一方, HFPO の $\beta$ 炭素へ PO が攻撃する場合は, 重合反応は進行しないと考えられる. GPC 測定で観測された屈折率の低い生成物は, 置換基を持たないオキ セタンをモノマーとしたときとは異なり，POの仕込み比を増や しても消失することはなかった，これは, HFPO の $\alpha$ 炭素への PO の攻撃によって進行する重合反応と平行して, HFPO の $\beta$ 炭 素へのPO の攻撃が起き, 副反応が進行していることが示唆され る. 副反応生成物としては HFPO の異性体 ( i ) もしくは, PO と HFPO からなる環状オリゴマー（ ii ）が考えられる.

\section{4 結 論}

HFPO と環状エーテルモノマーとの反応による重合について
検討した結果, 以下のことが明らかとなった. HFPO と環状 エーテルモノマーは触媒を必要とせずに反応する，このとき，重 合はカチオン機構で進行するが, この種の環状エーテルのカチオ ン重合においては連鎖移動反応は少なく，無溶媒で行った本重合 ではそれは無視できると考えられるので, 生成物となる重合体の 分子量は, 環状エーテルモノマーの単独重合能に大きく影響され る.そのため，オキセタンを使用したときに最も分子量は高くな るが，THP を使用したときには高分子体は得ることはできな い。また，PO を用いたときには開始段階での求核反応が $\mathrm{HFPO}$ の $\alpha$ と $\beta$ の両方の炭素に対して起きる. $\beta$ 炭素に対して攻撃が行 われた場合には重合は停止し，重合体中に $\mathrm{CF}_{2}$ を持つ生成物が 生成される. $\mathrm{PO}$ は $\alpha, \beta$ の双方で開裂が起こるため, 生成され る重合体は複雑な主鎖配列を持つ.

本研究は東京応化技術振興財団研究費によったことを記し，謝 意を表する.

1) H. Millauer, W. Schwerfeger, G. Siegemund, Angew. Chem. Int. Ed. Engl., 24, 161(1985).

2) J. T. Hill, J. Macromol. Sci. Chem., A8, 499(1974).

3) U. S. Patent, 4302608A (1981).

4) J. T. Hill, J. P. Erdman, ACS Symp. Ser., 59, 269 (1977).

5) 山辺正顕, 松尾 仁, “フッ素系材料の開発”, シーエム シー(1994)

6) T. G. Shchibrya, S. P. Krukovskii, A. V. Ignatenko, V. A. Ponomarenko, Vyskomol. Soedin. Ser., B21 517(1979).

7）石川展男, 有機合成化学協会誌, 35, 131(1977).

8）大津隆行, “改訂高分子合成の化学”, 化学同人 (1979).

\title{
Polymerization of Cyclic Ethers Initiated by the Reaction of Cyclic Ether with Hexafluoropropylene Oxide
}

\author{
Yasuyuki Masubuchi, Tokio HagiwaRA ${ }^{*, \dagger}$, Youichi IKEGAYA ${ }^{\dagger}$, \\ Seiji KAWATA ${ }^{\dagger}$ and Noriyuki YonEZAWA
}

Department of Organic and Polymer Materials Chemistry, Tokyo University of Agriculture and Technology; 2-24-16 Nakamachi, Koganei-shi 184-8588 Japan

${ }^{\dagger}$ Department of Applied Chemistry, Saitama Institute of Technology; 1690 Fusaiji, Okabe, Saitama 369-02 Japan

The polymerization of cyclic ethers initiated by the reaction of cyclic ethers with hexafluoropropylene oxide (HFPO) were examined. When tetrahydropyrane (THP) was used as a monomer, the polymer could not be obtained.

When oxetane was used as a monomer, both yield and molecular weight of the obtained polymer were higher than those obtained in the polymerization using the other cyclic ethers as monomers. This is probably due to the highest homopolymerization reactivity of oxetane of the comonomers used.

The polymer obtained in the polymerization of $\mathrm{PO}$ had the different structure from that of the other polymers. The steric bulkiness and occurring of both $\alpha$-and $\beta$-ring cleavage of PO probably lead to specific structure of the resulting polymer. 